\title{
Analysis of Islamic Bank's Soundness Level Using Capital Ratio, Profitability, Financing, and Credit Risk
}

\author{
Muhammad Tho'in \\ Institut Teknologi Bisnis AAS Indonesia \\ \{thoinsyakira@yahoo.com\}
}

\begin{abstract}
The aims of the research are to find out the soundness level of Islamic banks seen from the capital ratio, profitability, financing, and credit. Islamic banking financial institutions which are the focus of this research are Bank Syariah Mandiri (BSM). This research uses quantitative descriptive methods. The data used are the 2014-2018 financial statements. The results of this study indicate that Bank Syariah Mandiri in terms of capital using the CAR ratio shows an average CAR ratio of $14.75 \%$. This means that BSM in terms of capital is ranked very well. Bank Syariah Mandiri in terms of profitability using the ROA and ROE ratio shows an average ROA of $0.53 \%$ and ROE of $6 \%$. This means that BSM's ability to generate profits is ranked quite well. Bank Syariah Mandiri in terms of financing using the FDR ratio shows an average FDR ratio of $79.81 \%$. This means that BSM's ability to repay short-term loans and meet agreed financing is at a healthy rating. Bank Syariah Mandiri in terms of credit risk using the NPF ratio shows an average NPF ratio of $3.18 \%$. This means that there is very little credit provided by BSM and the bank is viewed from the aspect of credit risk, including in a good rating. From the results of these studies, indicate that the soundness level of Bank Syariah Mandiri is in a good level of soundness.
\end{abstract}

Keywords: Bank Health, Capital, Profitability, Financing, Credit Risk

\section{Introduction}

Society in conducting economic activities at this time can almost be said to be inseparable from the name of financial institutions, especially financial institutions in the form of banking. Financial sector surplus to save money and financial sector deficit to make loans. For people who have more unused finances in depositing their money in a bank, of course, choose a bank that has a good level of health or even very good, they do it in order to provide peace and security when they deposit their money in the bank. Banking performance especially financial performance will be the concern of its customers (Farooq \& Zaheer, 2015); (Rozzani \& Rahman, 2013); (Al-Hares, et.al, 2013); (Amelia, 2015).

Viewed from a Islamic perspective, banks in Indonesia consist of two types, namely Islamic Banks and Conventional Banks. The difference lies in the principle used. Conventional banks use interest in operating and are principled to achieve maximum profits. Based on the provisions of Islamic law the imposition of interest is usury. This practice of 
usury in Islam is a very and forbidden thing and is a grave sin (Alamgir, 2016); (Gilani, 2015). Whereas Islamic banks operate using profit sharing principles and there is no usury practice. Islamic banks operating in accordance with the principles of Islamic law and banks whose operating procedures refer to the provisions of the Qur'an and Hadith (Wilardjo, 2005); (Iqbal \& Molyneux, 2016); (Jalil \& Rahman, 2010); (Wulandari \& Subagio, 2015).

Islamic banks are part of Islamic entities that function as intermediary institutions which are expected to be able to present themselves better compared to non-Islamic banks. The birth of Islamic banks with a different concept, namely to prohibit the application of interest in all banking transactions because it includes the category of usury (Tho'in, Irawati \& Lee, 2018); (Nasim \& Mediawati, 2019); (Chong \& Liu, 2009); (Farooq, 2011); (Uusmani \& Taqî

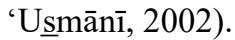

Muslims in particular and the general public certainly really hope that Islamic banks in Indonesia can develop properly, their health levels are good. To measure the soundness of government banks through Bank Indonesia has issued regulation number 13/1 / PBI / 2011 issued on January 5, 2011 concerning the rating of soundness of commercial banks. Then more details about the procedures for the evaluation are explained in Bank Indonesia Circular Letter number 13/24 / DPNP dated October 25, 2011.

Banks according to the Big Indonesian Dictionary are business entities in the financial sector that attract and spend money in society, especially providing credit and services in the payment traffic and circulation of money (Indonesia, K.B.B., \& Bahasa, T.P.K.P., 2015). Islamic according to the Big Indonesian Dictionary is a religious law that sets the rules of human life, human relations with God, human relations with humans, and the natural environment based on the Koran and Hadith (Indonesia, K.B.B., \& Language, T.P.K.P., 2015).

Financial statements in Islamic bank accounting are financial statements that describe the function of Islamic banks as investors, rights and obligations, regardless of the objectives of Islamic banks from investment problems, whether economic or social (Hassan \& Harahap, 2010). The purpose of making financial statements is to provide information about financial position, financial performance and cash flow that is beneficial for various parties using the report in making economic decisions (Iatridis, 2010); (Minnis, 2011); (Tho'in, 2019). Through financial statements the ability of a company to meet its short-term obligations can be assessed, the company's capital structure, distribution and effectiveness of the use of assets, results of operations/revenues that have been achieved, expenses to be paid and book values of each share of the company concerned.

Central Bank Regulation (BI) concerning the evaluation of the soundness of commercial banks is Bank Indonesia Regulation number 13/1 / PBI / 2011 issued on January 5, 2011. Then more details about the procedures for the assessment are explained in Bank Indonesia Circular Letter number 13/24 / DPNP dated 25 October 2011. Rating of the Bank's Soundness based on the regulation includes an assessment of the following factors: Risk Profile, Good Corporate Governance, Earning, and Capital Capital.

Bank Syariah Mandiri is the first conventional commercial bank in Indonesia that first opened a Islamic business unit which was then followed by other conventional commercial banks. Its existence in the increasingly fierce competition in its business, shows that this bank is very attractive to the public and able to maintain its financial performance well (healthy banks). Based on the above review, the researcher is interested in examining the soundness of Bank Syariah Mandiri (BSM) in terms of capital, profitability, financing ratios, and credit risk. 


\section{Research Method}

This research uses quantitative descriptive methods. The data used are financial statements published by Bank Syariah Mandiri (BSM) for the 2014-2018 period (for 5 years). The method of analysis in this study is to use the formula for calculating CAR (capital ratio), ROA and ROE (profitability), FDR (financing), and NPF (credit risk).

\section{Research Result}

Financial Highlights at Bank Syariah Mandiri continues to experience fluctuations from 2014-2018. Broadly speaking, Bank Syariah Mandiri Financial Reports are illustrated in the table below:

Table 1. BSM Financial Highlights 2014-2018

\begin{tabular}{lccccc}
\hline \multirow{2}{*}{ Financial (RP billion) } & \multicolumn{5}{c}{ Year } \\
\cline { 2 - 6 } & $\mathbf{2 0 1 4}$ & $\mathbf{2 0 1 5}$ & $\mathbf{2 0 1 6}$ & $\mathbf{2 0 1 7}$ & $\mathbf{2 0 1 8}$ \\
\hline Balance sheet & 4.937 & 5.613 & 6.392 & 7.314 & 8.039 \\
Capital & 5.570 & 6.187 & 6.942 & 7.844 & 8.566 \\
Core Capital, Complementary, Additional & 66.955 & 70.369 & 78.831 & 87.915 & 98.341 \\
Total assets & 59.821 & 62.113 & 69.950 & 77.903 & 87.471 \\
Third party funds & 37.746 & 48.146 & 49.555 & 49.350 & 52.670 \\
ATMR & 32.654 & 33.443 & 34.787 & 34.739 & 37.007 \\
Funding provided & & & & & \\
Problematic financing & 2.637 & 3.095 & 2.479 & 1.880 & 1.154 \\
Special attention & 601 & 530 & 355 & 470 & 206 \\
Substandard & 208 & 201 & 215 & 347 & 101 \\
Doubted & 601 & 509 & 701 & 89 & 289 \\
Stop & & & & & \\
Profit and Loss & 110 & 374 & 434 & 487 & 815 \\
Profit before tax & 99 & 369 & 442 & 470 & 839 \\
Operating profit & 2.451 & 2.438 & 2.339 & 2.541 & 2.659 \\
Profit sharing expense & 72 & 289 & 325 & 365 & 605 \\
Net profit & Source: Annual Report 2014-2018 & & \\
\hline &
\end{tabular}

Based on the annual report in the above table, it shows that overall the position or level of health of Bank Syariah Mandiri during the 2014-2018 period was in very good condition.

\subsection{Bank Syariah Mandiri (BSM) Soundness Assessment from the Capital Factor by Using the CAR Ratio}

Table 2. Calculation of Capital (CAR) and Rating of BSM Ratings 2014-2018

\begin{tabular}{cccccc}
\hline Year & Capital (Rp) & ATMR (Rp) & CAR & Ranking & Predicate \\
\hline 2014 & 5.570 .000 .000 .000 & 37.746 .000 .000 .000 & $14,76 \%$ & 1 & Very good \\
2015 & 6.187 .000 .000 .000 & 48.146 .000 .000 .000 & $12,85 \%$ & 1 & Very good \\
2016 & 6.942 .000 .000 .000 & 49.555 .000 .000 .000 & $14,01 \%$ & 1 & Very good \\
2017 & 7.844 .000 .000 .000 & 49.350 .000 .000 .000 & $15,89 \%$ & 1 & Very good \\
2018 & 8.566 .000 .000 .000 & 52.670 .000 .000 .000 & $16,26 \%$ & 1 & Very good \\
\hline
\end{tabular}

Source: data processed 
The results of calculating the CAR ratio using a predetermined formula are known that the CAR 2014 of $14.76 \%$. In 2015 it decreased by $1.91 \%$ to $12.85 \%$. From 2016 to 2018 there has always been an increase. In 2016 it increased by $1.16 \%$ to $14.01 \%$. In 2017 the increase was $1.88 \%$ to $15.89 \%$ and in 2018 there was an increase of $0.37 \%$ to $16.26 \%$. In the table above it can be seen that the highest CAR value was achieved in 2018. This means that the capital factor during that period was very good.

\subsection{Bank Syariah Mandiri (BSM) Soundness Assessment from Profitability Factors Using ROA and ROE Ratios}

Table 3. Calculation of Profitability (ROA) and Rating Rating for BSM 2014-2018

\begin{tabular}{cccccc}
\hline Year & Profit before tax (Rp) & Total Asset (Rp) & ROA & Ranking & Predicate \\
\hline 2014 & 110.000 .000 .000 & 66.955 .000 .000 .000 & $0,16 \%$ & 4 & Not good \\
2015 & 374.000 .000 .000 & 70.369 .000 .000 .000 & $0,53 \%$ & 3 & Good enough \\
2016 & 434.000 .000 .000 & 78.831 .000 .000 .000 & $0,55 \%$ & 3 & Good enough \\
2017 & 487.000 .000 .000 & 87.915 .000 .000 .000 & $0,55 \%$ & 3 & Good enough \\
2018 & 815.000 .000 .000 & 98.341 .000 .000 .000 & $0,83 \%$ & 3 & Good enough \\
\hline \multicolumn{5}{c}{ Source: data processed }
\end{tabular}

The results of calculating the ROA ratio using a predetermined formula note that 2014 ROA of $0.16 \%$. In 2015 up to 2018 there has always been an increase. In 2015 ROA became $0.53 \%$, in 2016 and 2017 ROA became $0.55 \%$ and in 2018 ROA at the highest position of $0.83 \%$. From these data it can be seen that in 2014 the ROA ratio was still not good. However, there has been an increase, where from 2015 until 2018 the ROA rating was always at position 3 , meaning that the bank's ability to generate profits in terms of assets owned is quite good.

Table 4. Calculation of Profitability (ROE) and Rating Assessment for BSM 2014-2018

\begin{tabular}{cccccc}
\hline Year & Profit after tax (Rp) & Average paid-up capital (Rp) & ROE & Ranking & Predicate \\
\hline 2014 & 72.000 .000 .000 & 4.937 .000 .000 .000 & $1,46 \%$ & 4 & Not good \\
2015 & 289.000 .000 .000 & 6.187 .000 .000 .000 & $5,15 \%$ & 3 & Enough good \\
2016 & 325.000 .000 .000 & 6.942 .000 .000 .000 & $5,08 \%$ & 3 & Enough good \\
2017 & 365.000 .000 .000 & 7.844 .000 .000 .000 & $4,99 \%$ & 4 & Not good \\
2018 & 605.000 .000 .000 & 8.566 .000 .000 .000 & $7,53 \%$ & 3 & Enough good \\
\hline \multicolumn{5}{c}{ Source: data processed } \\
\hline
\end{tabular}

ROE ratio calculation results using a predetermined formula note that the 2014 ROE of $1.46 \%$. There was a significant increase in 2015 to $5.15 \%$. Furthermore in 2016 amounted to $5.08 \%$, in 2017 there was a decrease to $4.19 \%$ and in 2018 ROE again increased and was at the highest position of $7.53 \%$. From these data it can be seen that in 2014 and 2017 the ROE ratio is still not good. However, there was also a significant increase in 2015 and 2018 . ROE rating is generally in position 3, meaning that the bank's ability to generate net profit from the capital deposit side is quite good.

\subsection{Bank Syariah Mandiri Health Assessment from Financing Factors Using the FDR Ratio}

Table 5. Calculation of Financing (FDR) and Rating Assessment for BSM 2014-2018

\begin{tabular}{llllll}
\hline Year & Given credit (Rp) & Third party funds (Rp) & FDR & Ranking & Predicate \\
\hline 2014 & 49.133 .000 .000 .000 & 59.821 .000 .000 .000 & 82,13 & 2 & Healthy \\
2015 & 51.090 .000 .000 .000 & 62.113 .000 .000 .000 & 82,25 & 2 & Healthy \\
\hline
\end{tabular}




\begin{tabular}{llllll}
\hline Year & Given credit (Rp) & Third party funds (Rp) & FDR & Ranking & Predicate \\
\hline 2016 & 55.580 .000 .000 .000 & 69.950 .000 .000 .000 & 79,46 & 2 & Healthy \\
2017 & 60.584 .000 .000 .000 & 77.903 .000 .000 .000 & 77,77 & 2 & Healthy \\
2018 & 67.752 .000 .000 .000 & 87.471 .000 .000 .000 & 77,46 & 2 & Healthy \\
\hline \multicolumn{5}{c}{ Source: data processed }
\end{tabular}

The calculating result of the FDR ratio using a predetermined formula are known that the 2014 FDR was $82.13 \%$. In 2015 it was $82.25 \%$. Development has always been better since 2016 at $79.46 \%$, then in 2017 at $77.77 \%$. FDR is best achieved in 2018 of $77.46 \%$. From these data it can be seen that from 2014 to 2018 the FDR rank was always ranked second. This means that the health of Bank Syariah Mandiri is based on the financing ratio (FDR) during the period in the healthy category.

\subsection{Bank Syariah Mandiri Soundness Assessment from Credit Risk Factors Using the NPF Ratio}

Table 6. Calculation of NPF and Rating Rating for BSM 2014-2018

\begin{tabular}{|c|c|c|c|c|c|}
\hline Year & Financing $(\mathrm{KL}, \mathrm{D}, \mathrm{M})(\mathrm{Rp})$ & Total financing (Rp) & NPF & Ranking & Predicate \\
\hline 2014 & 1.410 .000 .000 .000 & 32.654 .000 .000 .000 & 4,32 & 2 & Good \\
\hline 2015 & 1.240 .000 .000 .000 & 33.443 .000 .000 .000 & 3,71 & 2 & Good \\
\hline 2016 & 1.271 .000 .000 .000 & 34.787 .000 .000 .000 & 3,65 & 2 & Good \\
\hline 2017 & 906.000 .000 .000 & 34.739 .000 .000 .000 & 2,61 & 2 & Good \\
\hline 2018 & 596.000 .000 .000 & 37.007 .000 .000 .000 & 1,61 & 1 & Very good \\
\hline
\end{tabular}

The results of the NPF ratio calculation using a predetermined formula note that the 2014 NPF was $4.32 \%$. \%. The following years there have always been better developments, starting in 2015 at $3.71 \%$, then in 2016 at $3.65 \%$, in 2017 at $2.61 \%$. NPF is best achieved in 2018 of $1.61 \%$. From these data it can be seen that from 2014 to 2017 the NPF rank has always been ranked second, which is a good predicate. Then in 2018 an increase in the title was very good. The average rating of all factors can be seen in the following table:

Table 7. Average BSM Ranking 2014-2018

\begin{tabular}{cccccc}
\hline Year & Factor & Ratio & Rating & Predicate & Average Ranking \\
\hline 2014 & CAR & $14,76 \%$ & 1 & Very good & 2,6 \\
& ROA & $0,16 \%$ & 4 & Not good & \\
& ROE & $1,46 \%$ & 4 & Not good & \\
& FDR & $82,13 \%$ & 2 & Healthy & \\
& NPF & $4,32 \%$ & 2 & Good & 2,2 \\
& CAR & $12,85 \%$ & 1 & Very good & \\
& ROA & $0,53 \%$ & 3 & Enough good & \\
& ROE & $5,15 \%$ & 3 & Enough good & \\
& FDR & $82,25 \%$ & 2 & Healthy & \\
& NPF & $3,71 \%$ & 2 & Good & \\
& CAR & $14,01 \%$ & 1 & Very good & \\
& ROA & $0,55 \%$ & 3 & Enough good & \\
& ROE & $5,08 \%$ & 3 & Enough good & \\
& FDR & $79,46 \%$ & 2 & Healthy & \\
& NPF & $3,65 \%$ & 2 & Good & \multirow{2}{*}{2,4} \\
& CAR & $15,89 \%$ & 1 & Very good & \\
& ROA & $0,55 \%$ & 3 & Enough good & \\
\hline
\end{tabular}




\begin{tabular}{cccccc}
\hline Year & Factor & Ratio & Rating & Predicate & Average Ranking \\
\hline \multirow{4}{*}{2018} & ROE & $4,99 \%$ & 3 & Enough good & \\
& FDR & $77,77 \%$ & 2 & Healthy & \\
NPF & $2,61 \%$ & 2 & Good & 2 \\
& CAR & $16,26 \%$ & 1 & Very good & \\
& ROA & $0,83 \%$ & 3 & Enough good & \\
& ROE & $7,53 \%$ & 3 & Enough good & \\
& FDR & $77,46 \%$ & 2 & Healthy & \\
NPF & $1,61 \%$ & 1 & Very good & 2,28 \\
Average Rating & & & Healthy \\
Predicate & &
\end{tabular}

Based on table 7 on the average rating, it can be seen that the results of the health assessment for the last five years Bank Syariah Mandiri is in a healthy predicate. From 2014 to 2018 the capital aspect shows that the CAR ratio is always ranked first. This means that the capital factor of Bank Syariah Mandiri during that period was very good. Then from the aspect of profitability, the ROA ratio in 2014 showed a bad predicate. However, from 2015 to 2018 the ROA ratio increased to be quite good. Likewise, the ROE ratio, the predicate is not good happened in 2014 and 2017. However, improvements occurred in 2015, 2016 and 2018 to be quite good, so that on average the title for five years is quite good. From this ratio, it can be seen that the ability to generate profit of Bank Syariah Mandiri both in terms of assets owned and in terms of paid up capital is quite good. The level of liquidity assessed from the 20142018 FDR ratio is ranked 2 or the predicate healthy. From this it follows that the level of the ability of Bank Syariah Mandiri to pay off its short-term obligations on time and the ability to fulfill all credit applications that have been approved is very good. The quality of Bank Syariah Mandiri financing can be seen from the NPF ratio with good predicate in 2014-2017, while in 2018 it has increased to a very good predicate.

\section{Conclusion}

Based on the results of the research analysis in the previous chapter, it can be concluded that the soundness level of Bank Syariah Mandiri (BSM) is based on an average rating using capital ratios, profitability ratios, financing ratios, and credit risk ratios for five years (20142018) including in healthy Islamic banks.

\section{References}

[1] Alamgir, Md. "An analysis of islamic banking activities in Bangladesh: Issues and challenges." Thoughts on Economics 25.03 (2016): 29-58.

[2] Al-Hares, Osama M., Naser M. AbuGhazaleh, and Ahmed Mohamed El-Galfy. "Financial performance and compliance with Basel III capital standards: Conventional vs. Islamic banks." Journal of Applied Business Research (JABR) 29.4 (2013): 10311048 .

[3] Amelia, Erika. "Financial Ratio and Its Influence to Profitability in Islamic Banks." AlIqtishad: Jurnal Ilmu Ekonomi Syariah 7.2 (2015): 229-240. 
[4] Chong, Beng Soon, and Ming-Hua Liu. "Islamic banking: interest-free or interestbased?." Pacific-Basin finance journal 17.1 (2009): 125-144.

[5] Farooq, Mohammad Omar. "Qarḍ Ḥasan, Wad̄̄ 'ah/Amānah and Bank Deposits: Applications and Misapplications of Some Concepts in Islamic Banking." Arab Law Quarterly 25.2 (2011): 115-146.

[6] Farooq, Moazzam, and Sajjad Zaheer. "Are Islamic banks more resilient during financial panics?." Pacific Economic Review 20.1 (2015): 101-124.

[7] Gilani, Hasan. "Exploring the ethical aspects of Islamic banking." International Journal of Islamic and Middle Eastern Finance and Management (2015).

[8] Hassan, Abul, and Sofyan Syafri Harahap. "Exploring corporate social responsibility disclosure: the case of Islamic banks." International Journal of Islamic and Middle Eastern Finance and Management (2010).

[9] Iatridis, George. "International Financial Reporting Standards and the quality of financial statement information." International review of financial analysis 19.3 (2010): 193-204.

[10] Indonesia, Kamus Besar Bahasa. "Edisi ketiga." Jakarta: Balai Pustaka (2005).

[11] Iqbal, Munawar, and Philip Molyneux. Thirty years of Islamic banking: History, performance and prospects. Springer, (2016).

[12] Jalil, Abdul, and Muhammad Khalilur Rahman. "Financial transactions in Islamic Banking are viable alternatives to the conventional banking transactions." International Journal of Business and Social Science 1.3 (2010).

[13] Minnis, Michael. "The value of financial statement verification in debt financing: Evidence from private US firms." Journal of accounting research 49.2 (2011): 457506.

[14] Nasim, Arim, and Elis Mediawati. "Critical Study the Application of the Principle of Profit Sharing in Syirkah Mudharabah and Musyarakah in Islamic Banking." KnE Social Sciences (2019): 1351-1359.

[15] Rozzani, Nabilah, and Rashidah Abdul Rahman. "Camels and performance evaluation of banks in Malaysia: conventional versus Islamic." Journal of Islamic Finance and Business Research 2.1 (2013): 36-45.

[16] Surat Edaran Bank Indonesia nomor 13/ 24 /DPNP tanggal 25 Oktober 2011. Penilaian Tingkat Kesehatan Bank mencakup penilaian terhadap faktor-faktor berikut: Profil Risiko, Good Corporate Governance, Earning, dan Capital Permodalan. Diakses pada tanggal 4 Maret 2020.

[17] Tho'in, Muhammad, Tri Irawati, and Mika Lee. "Risk and Financial Health Level of Shariabanking." Journal Research and Analysis: Economy 1.1 (2018): 19-26.

[18] Tho'in, Muhammad. "Profitability of Islamic Commercial Banks in Indonesia." MEC-J (Management and Economics Journal) 3.3 (2019): 277-288.

[19] Uusmani, Muhammad Taqi, and Muhammad Taqī 'Unsmānī. An introduction to Islamic finance. Vol. 20. Brill, (2002).

[20] Wilardjo, Setia Budhi. "pengertian, peranan dan perkembangan bank syari'ah Di Indonesia." Value Added| Majalah Ekonomi Dan Bisnis 2.1 (2005).

[21] Wulandari, Deasy, and Ari Subagio. "Consumer decision making in conventional banks and islamic bank based on quality of service perception." Procedia-Social and Behavioral Sciences 211 (2015): 471-475. 